\title{
Structural study of a series of synthetic goethites obtained in aqueous solutions containing cadmium(II) ions
}

\author{
E. E. Sileo a) and P. S. Solís \\ INQUIMAE, Facultad de Ciencias Exactas y Naturales, Universidad de Buenos Aires, Ciudad Universitaria, \\ Pab. II, Piso 3, C1428EHA, Buenos Aires, Argentina \\ C. O. Paiva-Santos \\ Instituto de Química, Universidade Estadual Paulista, UNESP, Araraquara, 14801-970 São Paulo, Brazil
}

(Received 3 June 2002; accepted 8 November 2002)

\begin{abstract}
The capacity of goethite for $\mathrm{Cd}^{\mathrm{II}}$ substitution has been explored in a series of synthetic samples prepared from $\mathrm{Fe}^{\mathrm{III}}$ and $\mathrm{Cd}^{\mathrm{II}}$ nitrate solutions aged 21 days in alkaline media. The total metal content $([\mathrm{Fe}]+[\mathrm{Cd}])$ was $0.071 \mathrm{M}$ in all preparations. The samples have been characterized by chemical and X-ray diffraction analysis; the morphology of the solids is described. The cell parameters for all samples were obtained by the Rietveld fits to the X-ray diffraction data. Refined structures show that for samples prepared at the final molar ratio $\mu_{\mathrm{Cd}} \leqslant 5.50$ (expressed as $\mu_{\mathrm{Cd}}=100 \times[\mathrm{Cd}] /[\mathrm{Cd}]$ $+[\mathrm{Fe}]), \mathrm{a}(\mathrm{Cd}, \mathrm{Fe})$-goethite is the only crystalline product. In these samples, the unit cell parameters increased as a function of $\mathrm{Cd}$ concentration, indicating $\mathrm{Cd}$ incorporation in the structural frame. At the preparative ratio, $\mu_{\mathrm{Cd}}=7.03$, the incorporation of $\mathrm{Cd}$ in the goethite structure is drastically reduced and a probable Cd-substituted hematite is formed together with the Fe,Cd-goethite. (C) 2003 International Centre for Diffraction Data. [DOI: 10.1154/1.1538188]
\end{abstract}

Key words: X-ray powder diffraction, Rietveld analysis, substituted goethite, cadmium, substituted hematite

\section{INTRODUCTION}

Goethite, $(\alpha-\mathrm{FeOOH})$, is widespread in the ecosystem, and it occurs in oxidizing and reducing environments. It is found in $\mathrm{Fe}$ ore deposits and is the most important iron oxide hydroxide present in river and marine sediments. The natural phase commonly occurs as very fine particles that accumulate heavy metals by adsorption and complexing and/or coprecipitation (Cornell and Schwertmann, 1996).

In alkaline media, goethite forms from ferrihydrite, the initial oxyhydroxide of Fe(III). Ferrihydrite is a metastable compound that may transform into goethite, hematite, or a mixture of the two, via two competing pathways. The interconversion to goethite proceeds via a dissolutionreprecipitation process (Fisher, 1971; Blesa and Matijevic, 1989). Formation of hematite involves a solid-state rearrangement (Feitknecht and Michaelis, 1962; Schwertmann and Fisher, 1966) that starts in denser zones within the ferrihydrite aggregate. Giovanoli and Cornell (1992) have shown that some first row transition elements stabilize ferrihydrite toward dissolution so that hematite forms more easily. Aluminum also promotes the formation of hematite, as this effect is attributed to a lower solubility of the Alcontaining ferrihydrite precursor relative to pure ferrihydrite (Schwertmann et al., 2000). The metal-mixed ferrihydrite may form substituted goethite and/or hematite.

Insertion in synthetic goethites has been demonstrated for the following elements: $\mathrm{Al}, \mathrm{Cr}, \mathrm{Cd}, \mathrm{Ni}, \mathrm{Ga}, \mathrm{Sc}, \mathrm{Ge}, \mathrm{Si}, \mathrm{U}$, Th, Co, Cu, Pb, V, Mn, and Zn (Norrish and Taylor, 1961; Lim-Numez and Gilkes, 1985; Stiers and Schwertmann, 1985; Vandenberghe et al., 1986; Cornell and Giovanoli, 1987, 1989; Diaz et al., 1989; Ebinger and Schulze, 1989;

a) Electronic mail: sileo@qi.fcen.uba.ar
Schwertmann et al., 1989; Gerth, 1990; Schwertmann and Pfab, 1994; Gasser et al., 1999; Manceau et al., 2000; Sileo et al., 2001).

Cadmium is a heavy metal that is known to bioaccumulate (Jin et al., 1998; Lehoczky et al., 1998). Its solutions are highly toxic to humans and many other biota. It occurs in some mine wastes and as a waste from various industrial activities. The $\mathrm{Cd}^{\mathrm{II}}$ ion is one of the species that may be adsorbed and/or coprecipitated from solution into $\mathrm{Fe}$ oxide hydroxides. As the ionic radius of $\mathrm{Cd}^{\mathrm{II}}$ is significantly larger than that of $\mathrm{Fe}^{\mathrm{III}}(0.0920$ vs $0.0615 \mathrm{~nm})$ the substitution may considerably alter the structural framework of pure goethite, changing its morphology and its physicochemical properties. The processes of $\mathrm{Cd}^{\mathrm{II}}$ uptake onto goethite surfaces have been fully analyzed (Forbes et al., 1979; Balistrieri and Murray, 1982; Venema et al., 1996; Collins et al., 1999; Parkman et al., 1999). However, only basic studies of cadmium incorporation into the structural frame of goethite have been reported (Gerth, 1990).

Goethite shows an orthorhombic unit cell with four groups $\mathrm{FeOOH}$. The structure is based on HCP packing of oxygen $\left(\mathrm{O}_{\mathrm{I}}\right)$ and hydroxide ions $\left(\mathrm{O}_{\mathrm{II}}\right)$ with half of the octahedral sites filled with $\mathrm{Fe}^{\mathrm{III}}$ ions. The structure may be described in terms of $\mathrm{Fe}$ octahedra $\left(\mathrm{FeO}_{3}(\mathrm{OH})_{3}\right)$ linked in pairs by an edge, through two $\mathrm{O}_{\mathrm{II}}$ atoms. These pairs form double chains that run parallel to [001] $(\mathrm{Pbnm})$. Along the chain, the octahedra are joined by edges through $\mathrm{O}_{\mathrm{I}}$ and $\mathrm{O}_{\mathrm{II}}$ atoms. Also each octahedron shares two corners $\left(\mathrm{O}_{\mathrm{I}}\right)$ with two polyhedra from a neighboring double row. This arrangement leads to double chains separated by vacant double rows (see Figure 1).

Cations $\mathrm{M}^{\mathrm{II}}$, $\mathrm{M}^{\mathrm{III}}$, and $\mathrm{M}^{\mathrm{IV}}$ may substitute into the octahedral Fe positions in the goethite structure; for $\mathrm{M}^{\mathrm{II}}$ and $\mathrm{M}^{\mathrm{IV}}$ substitution, an uptake or release of protons is expected, to 


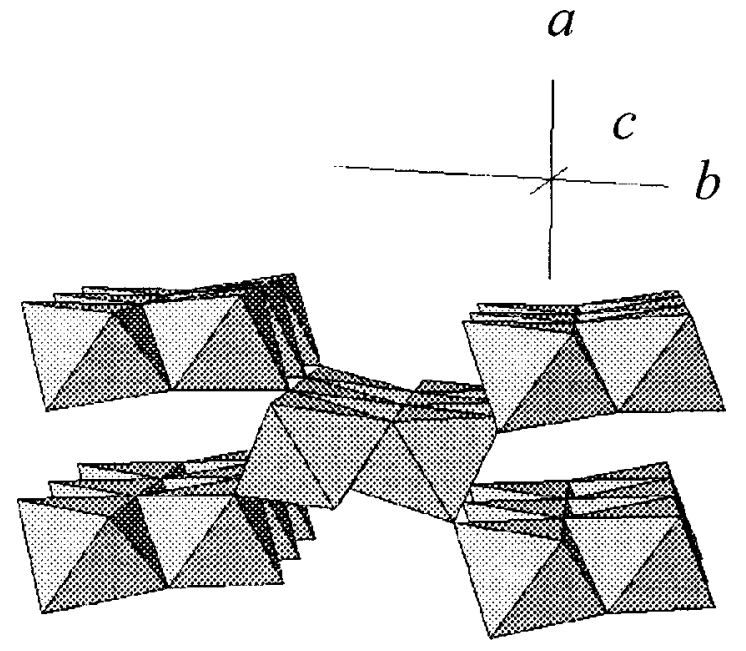

Figure 1. Arrangement of polyhedra in the structure of goethite, the octahedra share edges within the rows, and vertices between chains.

account for charge balance. Although $\mathrm{Fe}^{\mathrm{III}}$ and $\mathrm{Cd}^{\mathrm{II}}$ have very different ionic radii, their electronic configuration is symmetric; $\mathrm{Fe}^{\mathrm{III}}$ is a $d^{5}$ and $\mathrm{Cd}^{\mathrm{II}}$ is a $d^{10}$ ion. Thus, in the Cd-for-Fe substitution, the symmetry of the coordination sphere for both ions is expected to be approximately undistorted and only an enlargement of the $a, b$, and $c$ parameters is expected.

In this work, we investigated the morphological and cell parameter variations for a series of $\alpha$-FeOOH samples synthesized from alkaline solutions of $\mathrm{Fe}^{\mathrm{III}}$ containing different concentrations of $\mathrm{Cd}^{\mathrm{II}}$ ions. We determined the concentration range in which cadmium is incorporated into the goethite structure, and the maximum capacity of $\mathrm{Cd}$ in goethite. As the synthetic Cd-rich goethites obtained are poorly crystalline, structural changes are quantified through the Rietveld analysis (Rietveld, 1969) of powder X-ray diffraction data.

\section{EXPERIMENTAL}

\section{A. Preparation of the solids}

Pure and Cd-rich goethites were prepared by adding at $70{ }^{\circ} \mathrm{C}, 50 \mathrm{~mL}$ of a $1 \mathrm{M}$ ferric nitrate or $1 \mathrm{M}$ iron plus cadmium nitrates solution, to $650 \mathrm{~mL}$ of sodium hydroxide solutions (final $\mathrm{OH}^{-}$concentration was in all cases $0.5 \mathrm{M}$ ). The suspensions obtained were aged for 21 days at $70^{\circ} \mathrm{C}$ in closed polyethylene flasks. Once a day, the flasks were vigorously shaken. The final products were centrifuged and washed three times with doubly distilled water. In order to remove any non-structurally incorporated cations or ferrihydrite from the surfaces of the products, an acid oxalate extraction (Schwertmann and Cornell, 1991) was carried out twice. After the extraction process, the solids were washed with doubly distilled water and dialyzed until the conductivity of the solution was similar to that of bidistilled water. Finally, the solids were dried for three days at $40^{\circ} \mathrm{C}$. Preparation molar ratio $\mu_{\mathrm{Cd}}$ for the samples, expressed as 100 $\times[\mathrm{Cd}] /[\mathrm{Cd}]+[\mathrm{Fe}]$, were $0 ; 0.99 ; 2.88 ; 3.63 ; 5.05$, and 7.03.

\section{B. Chemical and morphological analysis}

The Fe and Cd content in the solids were measured using a Varian Techtrom A-A5R atomic absorption spectrometer.
TABLE I. Chemical analyses for the samples.

\begin{tabular}{ccc}
\hline \hline Sample & Preparation ratio $^{\mathrm{a}}$ & Cd content $^{\mathrm{a}}$ \\
\hline $\mathrm{S}_{0}$ & 0 & 0 \\
$\mathrm{~S}_{1}$ & 0.99 & $0.96-1.06$ \\
$\mathrm{~S}_{2}$ & 2.74 & $4.05-4.06$ \\
$\mathrm{~S}_{3}$ & 3.63 & $4.55-4.56$ \\
$\mathrm{~S}_{4}$ & 5.50 & $5.91-5.98$ \\
$\mathrm{~S}_{5}$ & 7.03 & $4.54-4.73$ \\
\hline \hline
\end{tabular}

${ }^{\text {a Cadmium content measured by duplicate and expressed as } 100}$ $\times[\mathrm{Cd}] /[\mathrm{Cd}]+[\mathrm{Fe}]$.

Morphological observations were carried out using a Philips 515 scanning electron microscope (SEM) operated at $30 \mathrm{keV}$.

\section{X-ray diffraction measurements}

Samples were hand-ground in an agate mortar and pestle, and side-loaded into an Al sample holder. XRD data were collected at the measurement conditions given in Table I. The step width, $0.025^{\circ}$, assured a minimum of about 12 intensity points for the narrower peaks.

\section{Structure refinements}

The structures were refined in the 2-theta range $18.500^{\circ}-131.000^{\circ}$ to ensure that only the specimen is irradiated. The Rietveld method was applied using the GSAS (General Structure Analysis System) program (Larson and Von Dreele, 1994). Starting unit-cell parameters and atomic coordinates for goethite (Szytula et al., 1980), space group Pbnm, $Z=4$ and hematite (Blake et al., 1966), space group $R-3 c, Z=6$, were taken from published works. Although the space group of goethite was reoriented to Pnma, in order to facilitate comparisons with previous works, we present the results of the refinements as goethite having the space group Pbnm. The measured background was fitted with a simple linear interpolation. The Thompson-Cox-Hasting pseudoVoigt function (Thompson et al., 1987) with the microstrain broadening description of Stephens (Stephens, 1999) was used for fitting peak profiles. Only the scale factors and the background coefficients were adjusted during the first cycles, and then gradually in successive cycles, the following parameters were varied in the least-squares refinement procedure: the sample displacement and the unit cell values, the size related LX and Xe and the strain related $S_{h k l}$ parameters, the asymmetry parameters for the peak shapes, and the atomic positional parameters. The isotropic thermal parameters were varied for all atoms. The preferred orientation was corrected using the March function (Dollase, 1986). The occupancy factor of the metal site, $f$, was refined in two stages, first, the starting occupancy factor of the $\mathrm{Cd}$ atom was fixed to $0.0\left(f_{\mathrm{Fe}}=1.0\right)$ and the occupancy factor of the site was obtained, then, and according to chemical analysis, the $\mathrm{Cd}$ ion was situated in the Fe position and the occupancy factors of $\mathrm{Cd}$ and $\mathrm{Fe}$ were refined; this two-step procedure is discussed later. In $\mathrm{S}_{5}$, containing goethite and hematite, $\mu_{\mathrm{Cd}}$ in the goethite phase was calculated from regression data as explained later. 
TABLE II. Results of the refinements for samples $\mathrm{S}_{0}-\mathrm{S}_{5}$.

\begin{tabular}{|c|c|c|c|c|c|c|c|c|c|c|c|}
\hline $\begin{array}{c}\text { Sample } \\
\text { (Anis. axis) }\end{array}$ & $R w p$ & $R p$ & $\chi^{2}$ & $R_{\text {Bragg }}$ & $\mathrm{Wt}(\%)$ & $\begin{array}{l}\text { Pref Or }(h k l) \\
\text { (ratio, fraction) }\end{array}$ & Ocup & $a(\mathrm{~nm})$ & $b(\mathrm{~nm})$ & $c(\mathrm{~nm})$ & $V\left(\mathrm{~nm}^{3}\right)$ \\
\hline $\mathrm{S}_{0}$ & 8.84 & 6.57 & 1.28 & 4.53 & 100 & $\begin{array}{c}021 \\
(1.04,0.99)\end{array}$ & $\begin{array}{l}\text { Fe: } \\
0.875(3)\end{array}$ & $0.46114(1)$ & $0.99589(2)$ & $0.30230(1)$ & $0.138830(6)$ \\
\hline$(001)$ & & & & & & $\begin{array}{c}140 \\
(1.36,0.01)\end{array}$ & $\begin{array}{l}\text { Cd: } \\
0.000\end{array}$ & & & & \\
\hline $\mathrm{S}_{1}$ & 9.25 & 6.64 & 1.49 & 3.33 & 100 & $\begin{array}{c}021 \\
(1.15,0.60)\end{array}$ & $\begin{array}{l}\text { Fe: } \\
0.879\end{array}$ & $0.46167(2)$ & $0.99704(4)$ & $0.30267(1)$ & $0.139316(12)$ \\
\hline$(021)$ & & & & & & $\begin{array}{c}140 \\
(1.10,0.40)\end{array}$ & $\begin{array}{l}\mathrm{Cd}: \\
0.010^{\mathrm{a}}\end{array}$ & & & & \\
\hline $\mathrm{S}_{2}$ & 9.53 & 7.40 & 1.53 & 5.26 & 100 & $\begin{array}{c}021 \\
(1.49,0.60)\end{array}$ & $\begin{array}{l}\text { Fe: } \\
0.799(1)\end{array}$ & $0.46233(3)$ & $1.00058(4)$ & $0.30343(1)$ & $0.140366(13)$ \\
\hline$(021)$ & & & & & & $\begin{array}{c}140 \\
(1.23,0.40)\end{array}$ & $\begin{array}{l}\mathrm{Cd}: \\
0.033(1)\end{array}$ & & & & \\
\hline $\mathrm{S}_{3}$ & 8.50 & 6.44 & 1.25 & 3.18 & 100 & $\begin{array}{c}021 \\
(1.13,0.55)\end{array}$ & $\begin{array}{l}\text { Fe: } \\
0.806(1)\end{array}$ & $0.46240(2)$ & $1.00107(3)$ & $0.30359(1)$ & $0.140512(05)$ \\
\hline$(021)$ & & & & & & $\begin{array}{c}140 \\
(1.01,0.45)\end{array}$ & $\begin{array}{l}\mathrm{Cd}: \\
0.038(1)\end{array}$ & & & & \\
\hline $\mathrm{S}_{4}$ & 9.02 & 6.89 & 1.42 & 4.99 & 100 & $\begin{array}{c}021 \\
(1.13,0.94)\end{array}$ & $\begin{array}{l}\text { Fe: } \\
0.861(4)\end{array}$ & $0.46255(3)$ & $1.00278(4)$ & $0.30393(1)$ & $0.140976(13)$ \\
\hline$(021)$ & & & & & & $\begin{array}{c}140 \\
(1.87,0.06)\end{array}$ & $\begin{array}{l}\mathrm{Cd}: \\
0.054(4)\end{array}$ & & & & \\
\hline $\mathrm{S}_{5}$ & 8.54 & 6.54 & 1.25 & 3.14 & $\begin{array}{c}89.14 \\
( \pm 0.09)\end{array}$ & $\begin{array}{c}021 \\
(0.96,0.43)\end{array}$ & $\begin{array}{l}\text { Fe: } \\
0.820(4)\end{array}$ & $\begin{array}{c}0.46245(4) \\
0.50543(5)^{\mathrm{b}}\end{array}$ & $\begin{array}{c}1.00213(6) \\
0.50543(5)^{b}\end{array}$ & $\begin{array}{c}0.30374(2) \\
1.38057(26)^{\mathrm{b}}\end{array}$ & $\begin{array}{c}0.140763(18) \\
0.305426(54)^{\mathrm{b}}\end{array}$ \\
\hline$(001)$ & & & & & $\begin{array}{l}10.86^{\mathrm{b}} \\
( \pm 0.25)\end{array}$ & $\begin{array}{c}140 \\
(0.99,0.57)\end{array}$ & $\begin{array}{l}\text { Cd: } \\
0.046(4)\end{array}$ & & & & \\
\hline
\end{tabular}

${ }^{a}$ Values in parentheses are uesd for the least significant figures of the data shown, and are taken from the final cycle of the Rietveld refinements.

${ }^{\mathrm{b}}$ Not refined.

${ }^{\mathrm{c}}$ Data for the hematite-like phase.

\section{RESULTS AND DISCUSSION}

\section{A. Chemical and XRD analysis of the solids}

Table II shows the preparation ratio and the chemical analysis for $\mathrm{Fe}$ and $\mathrm{Cd}$ for samples $\mathrm{S}_{0}$ to $\mathrm{S}_{5}$. The metal content of each sample was determined by duplicate. Electron microscopy observations of the solids were performed to rule out the presence of $\mathrm{Cd}$ and/or $\mathrm{Fe}$ amorphous materials or traces of metal oxides not detectable by XRD. As can be seen, from $S_{1}$ to $S_{4}$, the level of cadmium incorporation increases in accordance with the preparation ratio. In $S_{5}$ the process is inverted and an increase in the $\mathrm{Cd}$ content of the initial solution provokes a decrease in the $\mathrm{Cd}$ content of the solid obtained.

In samples $S_{2}-S_{4}$, the $\mu_{C d}$ in the final sample is higher than the preparation ratio; this fact is attributed to the extraction process by which only $\mathrm{Fe}$ amorphous phases are dissolved by the oxalic-oxalate solution.

Figure 2 presents the XRD diagrams obtained for the six samples prepared. For $S_{0}$ to $S_{4}$, the only phase detected was goethite (PDF: 29-0713) and a peak displacement to smaller $2 \theta$ values was observed as the $\mathrm{Cd}$ content in the sample increased. For $\mathrm{S}_{5}$ new peaks are present at $2 \theta: 24.22^{\circ}$ and $49.32^{\circ}$. These additional peaks indicate the presence of hematite (PDF: 33-0664).

\section{B. Crystal morphology}

Morphological information obtained via electron microscopic imaging was obtained for all samples. Figure 3 shows the scanning electron micrographs (SEM) of samples $\mathrm{S}_{0}, \mathrm{~S}_{1}$, $\mathrm{S}_{4}$, and $\mathrm{S}_{5} \cdot \mathrm{S}_{0}$ (pure goethite) displays a variety of acicular habits where some lengthy needles (average $1.3 \times 0.2 \mu \mathrm{m}$ ) coexist with a majority of short needles (average 0.5 $\times 0.2 \mu \mathrm{m})$ and star-shaped twins. From $S_{1}$ to $S_{4}$, stars are present together with needles where the length-to-width ratio is increased; the largest length-to-width ratio is found in $S_{3}$ (average $1.2 \times 0.1 \mu \mathrm{m}$ ). A change in morphology is detected in $S_{5}$ where only a few stars are present with needles that show a drastic reduction in crystal lengths (average 0.6 $\times 0.1 \mu \mathrm{m}$ and $0.3 \times 0.1 \mu \mathrm{m})$. Some imperfections in crystal morphologies observed by SEM pictures in substitutedgoethites, were probably caused by the extraction processes.

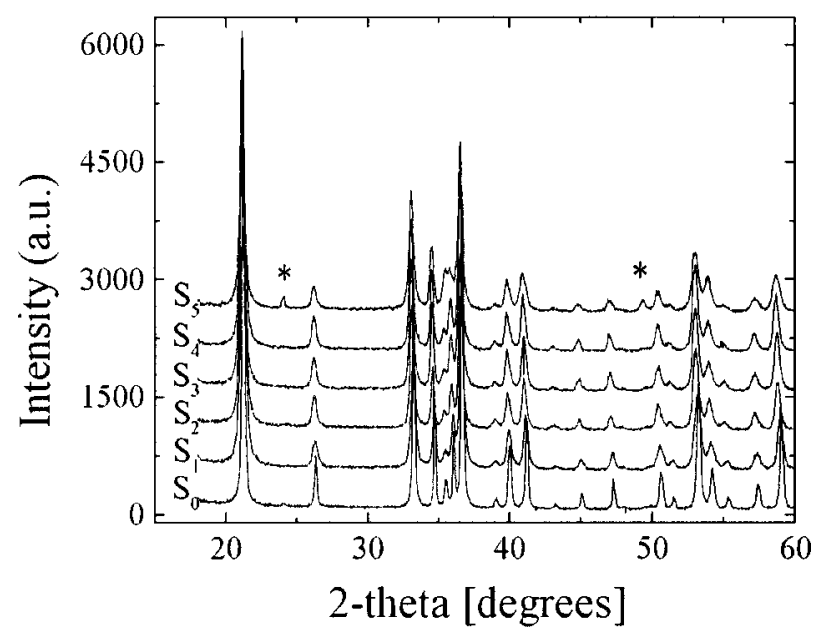

Figure 2. XRD diagrams for samples $S_{0}$ to $S_{5}$, the asterisks $(*)$ show the formation of hematite in $S_{5}$. 


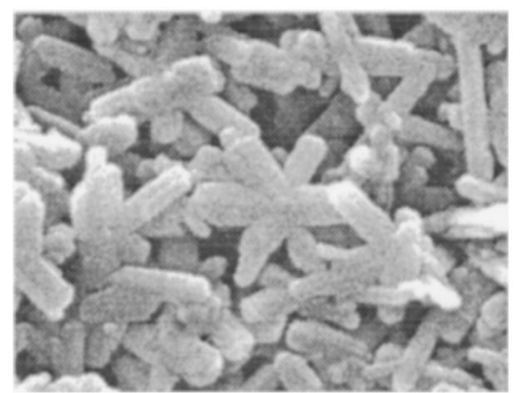

$\mathrm{S}_{\mathbf{0}}$

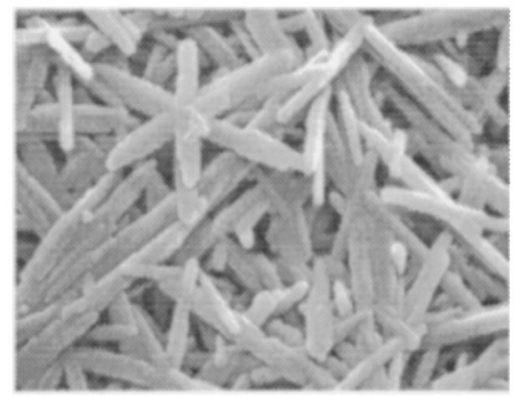

$\mathrm{S}_{4}$

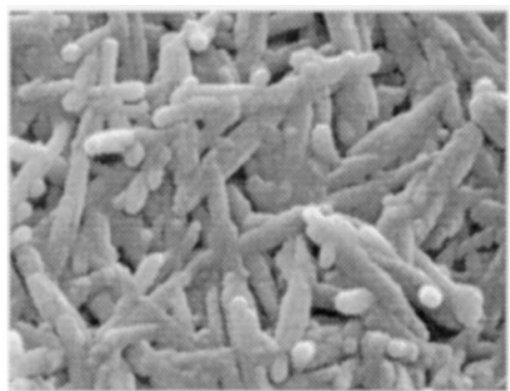

$\mathbf{S}_{1}$

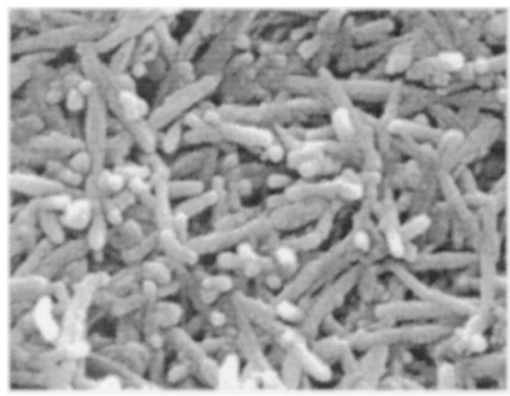

$\mathrm{S}_{5}$
Figure 3. SEM images for selected samples (magnification $40000 \times$ ) showing the needles and some star-like crystals and the increment of the length-to-width ratio from $S_{0}$ to $S_{4}$. The drastic change in morphology of sample $S_{5}$, is also shown.

\section{Results of the X-ray diffraction refinements}

The structure of sample $S_{5}$ was refined considering the two phases, goethite and hematite. Several values of the preferred orientation function were used during the refinement, but only the 021 and 140 planes markedly improved the quality of the refinements. All samples show both preferred orientations but the ratio and the fraction changed from one sample to another (cf. Table II). The 140 plane showed the highest ratio in $S_{0}$ and $S_{4}$ (1.36 and 1.88, respectively), in contrast the corresponding fractions were small $(0.01$ and $0.06)$.

Anisotropic line-shape broadening was detected in the solids; from $\mathrm{S}_{1}$ to $\mathrm{S}_{4}$, the anisotropic broadening axis was 021 , and in $S_{0}$ and $S_{5}$, was 001 . The reliability factors for
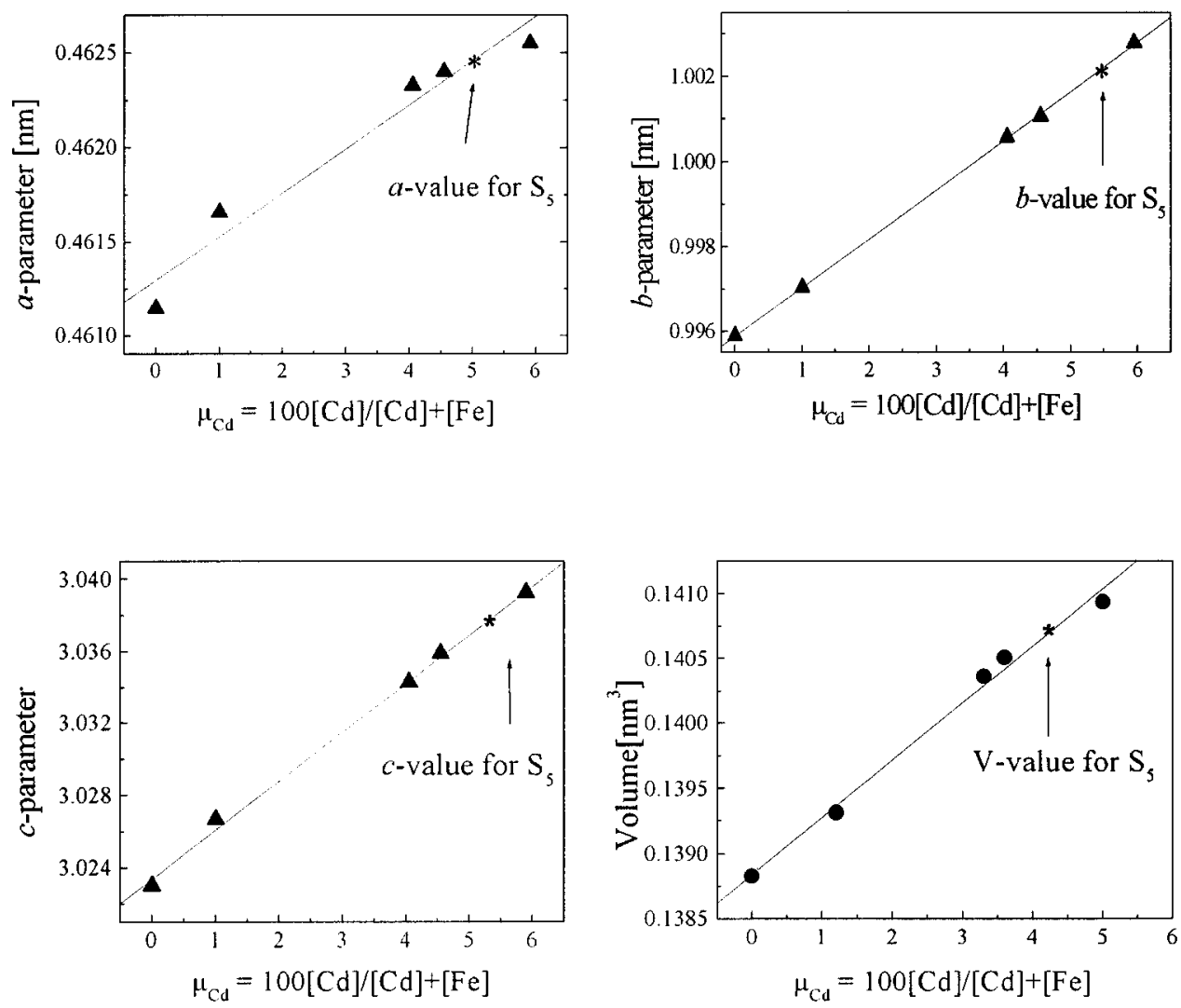

Figure 4. Lattice parameters and cell volume for the goethite phase vs \% total Cd content in samples $S_{0}$ to $S_{5}$. 


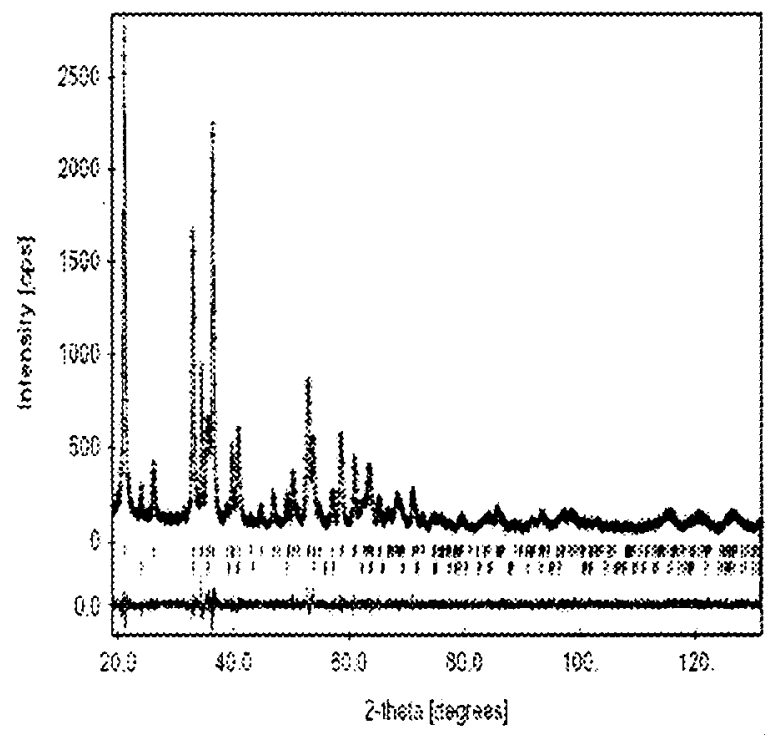

Figure 5. Observed $(+)$, calculated $(-)$ profiles, and difference plots for the Rietveld refinement of $S_{5}$. Positions of the Bragg peaks for the goethite and hematite phases are also shown (from top to bottom).

$\mathrm{S}_{0}-\mathrm{S}_{5}$ are presented in Table II. $R w p, G o F$, and $R_{\text {Bragg }}$ values are in the range 8.84-9.53,1.3-1.5, and 2.94-5.26, respectively, and they are, in general, satisfactory.

In all samples, the refined metal occupancy factor $\left(f_{\mathrm{Fe}+\mathrm{Cd}}\right)$ is smaller than 1.0 , the $f_{\mathrm{Fe}+\mathrm{Cd}}$ values varied between 0.832 and 0.915 (see Table II). This fact indicates the presence of cation-deficient compounds of the type $\alpha-\left(\mathrm{Fe}_{1-x} \mathrm{Me}_{x}\right)_{1-y / 3} \mathrm{O}_{1-y}(\mathrm{OH})_{1+y}$, where the $\mathrm{OH} / \mathrm{O}$ ratio exceeds the expected 1.0 value. Similar features have been observed in Al(III)-(Wolska and Schwertmann, 1989) and $\mathrm{Cr}(\mathrm{III})$-goethites (Sileo et al., unpublished). After this step, and keeping constant the refined $f_{\mathrm{Fe}+\mathrm{Cd}}$ value, the single $f_{\mathrm{Fe}}$ and $f_{\mathrm{Cd}}$ occupancy factors were also refined. The obtained $f_{\mathrm{Cd}} / f_{\mathrm{Fe}}+f_{\mathrm{Cd}}$ relations agree with the Cd contents obtained from the chemical analyses thus confirming a complete isostructural Cd-for-Fe substitution.

The calculated lattice parameters and unit-cell volume for the sample $S_{0}-S_{4}$ are listed in Table II. A plot of these values versus the total cadmium content in the sample $\left(\mu_{\mathrm{Cd}}\right)$ is shown in Figure 4. As $\mu_{\mathrm{Cd}}$ in the goethite phase was not available for sample $S_{5}$, it was obtained from an initial fit where the cell parameters were refined. From these cell parameters and the corresponding linear regressions, an average $\mu_{\mathrm{Cd}}$ was calculated (estimated $\mu_{\mathrm{Cd}}$ value from linear regression was 5.46). This value was used in the final refinement of $\mathrm{S}_{5}$.

A plot of the observed and the calculated data for $\mathrm{S}_{5}$ is given in Figure 5. As can be observed, the experimental diagram is well described by the goethite and the hematite-like structural models that have been employed.

Figure 4 shows that the unit cell parameters increase with the increase of $\mathrm{Cd}$ content in the solid in agreement with $\mathrm{Cd}$ incorporation in the frame structure. An abrupt change is observed in $S_{5}$ where a reduction in cell parameters is detected for the goethite phase. At this highest preparative condition, as indicated by the chemical analyses and Rietveld refinement, the total incorporation of $\mathrm{Cd}$ is decreased and the formation of hematite becomes competitive with that of the Cd-substituted goethite. In turn, $a$ and $c$ parameters for the hematite-phase are larger than reported (0.5054(1) and 1.3806(3) nm vs 0.5034 and $1.3752 \mathrm{~nm}$ ), indicating a partial Cd-for-Fe substitution in the hematite structure.

\section{CONCLUSION}

In the preparative range $\mu_{\mathrm{Cd}}=0.99-7.03$, the results obtained confirm the incorporation of $\mathrm{Cd}^{\mathrm{II}}$ in the goethite framework. According to the Rietveld refinements, the maximum Cd-for-Fe substitution in the goethite structure was $\mu_{\mathrm{Cd}}=5.90$, and was achieved at the preparative condition $\mu_{\mathrm{Cd}}=5.50$. At the preparation ratio $\mu_{\mathrm{Cd}}=7.03$, nucleation of hematite is started within the Cd-rich ferrihydrite aggregate hindering the formation of goethite, and the formation of hematite becomes competitive with that of the Cd-substituted goethite. The values of the cell parameters reveal that the $\mathrm{Cd}$ incorporation in the goethite phase diminishes in favor of Cd-substituted hematite.

This work indicates that goethite binds significant amounts of $\mathrm{Cd}$ through $\mathrm{Cd}$-for-Fe substitution and can control the $\mathrm{Cd}$ distribution and concentration in aqueous systems. The formation of goethite in $\mathrm{Cd}$ containing solutions may be used to remove the metal from waste water and liquid waste.

\section{ACKNOWLEDGMENTS}

This work was supported by a grant from Universidad de Buenos Aires (I015, RS 5009/2000). The authors acknowledge M. Villegas for SEM measurements.

Balistrieri, I. S. and Murray, J. W. (1982). "The Adsortion of $\mathrm{Cu}, \mathrm{Pb}, \mathrm{Zn}$ and Cd on Goethite from Mayor Ion Seawater," Geochim. Cosmochim. Acta 46, 1253-1265.

Blake, R. L., Hessevick, R. E., Zoltai, T., and Finger, L. W. (1966). "Refinement of the Hematite Structure," Am. Mineral. 74, 177-186.

Blesa, M. A. and Matiejevic, E. (1989). "Phase Transformations of iron oxides, oxohydroxides, and hydrous oxides in aqueous media," Ad. Coll. and Int. Science 29, 173-221.

Collins, C. R., Vala Ragnarsdottir, K., and Sherman, D. M. (1999). "Effect of Inorganic and Organic Ligands on the Mechanism of Cadmium Sortion to Goethite," Geochim. Cosmochim. Acta 63, 1989-3002.

Cornell, R. M. and Giovanoli, R. (1987). "Effect of Manganese on the Transformation of Ferrihydrite into Goethite and Jacobsite in Alkaline Media," Clays Clay Miner. 35, 11-20.

Cornell, R. M. and Giovanoli, R. (1989). "Effect of Cobalt on the Formation of Crystalline Iron Oxides from Ferrihydrites in Alkaline Media," Clays Clay Miner. 37, 65-70.

Cornell, R. M. and Schwertmann, U. (1996). "The Iron Oxides: Structure, Properties, Reactions, Occurrence and Uses," 573, VHC, New York.

Diaz, C., Furet, N. R., Nikolaev, V. L., Rusakov, V. S., and Cordeiro, M. C. (1989). "Mössbauer Effect Study of Co, Ni, Mn, and Al Bearing Goethites," Hyperfine Interact. 46, 689-693.

Dollase, W. A. (1986). "Corrections of Intensities for Preferred Orientations in Powder Diffractometry: Applications of the March Model," J. Appl. Crystallogr. 19, 267-272.

Ebinger, M. H. and Schulze, D. G. (1989). "Mn-substituted Goethite and Fe-substituted Groutite Synthesized at Acid pH," Clays Clay Miner. 37, $151-156$

Feitknecht, W. and Michaelis, W. (1962). "Über die Hydrolyse von Eisen(III)-perchlorat-Lösungen,” Helv. Chim. Acta 45, 212-224.

Fisher, W. R. (1971). "Modellversuche zur Bildung und Auf-lösung von Goethit und amorphen Eisenoxiden im Bodem," Diss. T. U. München. 
Forbes, E. A., Posner, A. M., and Quirk, J. P. (1979). "The Specific Adsorption of Divalent $\mathrm{Cd}, \mathrm{Co}, \mathrm{Cu}, \mathrm{Pb}$ and $\mathrm{Zn}$ on Goethite," J. Soil Sci. 27, $154-166$.

Gasser, U. G., Nuesch, R., Singer, M. J., and Jeanroy, E. (1999). “Distribution of Manganese in Synthetic Goethite," Clay Miner. 34, 291-299.

Gerth, J. (1990). "Unit-cell Dimensions of Pure and Trace Metal-associated Goethites," Geochim. Cosmochim. Acta 54, 363-371.

Giovanoli, R. and Cornell, R. M. (1992). "Crystallization of Metal Substituted Ferrihydrites," Z. Pflanzenernahr. Bodenk. 155, 455-460.

Jin, T. Y., Lu, J., and Nordberg, M. (1998). "Toxicokinetics and Biochemistry of Cadmium with Special Emphasis on the Role of Metallothionein," Neurotoxicology 19, 529-535.

Larson, A. C. and Von Dreele, R. B. (1994). General Structure Analysis System (GSAS), Los Alamos National Laboratory report LAUR 86-748.

Lehoczky, E., Szabo, L., Horvath, S., Marth, P., and Szabados, I. (1998). "Cadmium Uptake by Lettuce in Different Soils," Comm. Soil. Sci. Plant Anal. 29, 1903-1912.

Lim-Numez, R. and Gilkes, R. J. (1985). "Acid Dissolution of Synthetic Metal-containing Goethites and Hematites,'” Proc. Int. Clay Conf. Clay Mineral Soc. Am., pp. 197-204.

Manceau, A., Schlegel, M. L., Musso, M., Sole, V. A., Gauthier, C., Petit, P. E., and Trolard, F. (2000). "Crystal Chemistry of Trace Elements in Natural and Synthetic Goethite," Geochim. Cosmochim. Acta 64, 36433661.

Norrish, K. and Taylor, R. M. (1961). "The Isomorphous Replacement of Iron by Aluminium in Soil Goethites," J. Soil Sci. 12, 294-306.

Parkman, R. H., Charnock, J. M., Bryan, N. D., Livens, F. R., and Vaughan, D. J. (1999). "Reactions of Copper and Cadmium Ions in Aqueous Solution with Goethite, Lepidocrocite, Mackinawite, and Pyrite," Am. Mineral. 84, 407-419.

Rietveld, H. M. (1969). "A Profile Refinement Method for Nuclear and Magnetic Structures," J. Appl. Crystallogr. 2, 65-71.

Schwertmann, U., Friedl, J., Stanjek, H., and Schulze, D. G. (2000). "The effect of Al on Fe Oxides. XIX Formation of Al-substituted Hematite from Ferrihydrite at $25^{\circ}$ and $\mathrm{pH} 4$ to 7," Clays Clay Miner. 48, 259-172.

Schwertmann, U., Gasser, U., and Sticher, H. (1989). "Chromium-for-iron
Substitution in Synthetic Goethites," Geochim. Cosmochim. Acta 53, 1293-1297.

Schwertmann, U. and Cornell, R. M. (1991). "Iron Oxides in the Laboratory," pp. 46, VHC, New York, USA.

Schwertmann, U. and Pfab, G. (1994). "Structural Vanadium in Synthetic Goethite," Geochim. Cosmochim. Acta 58, 4349-4352.

Schwertmann, U. and Fisher, W. R. (1966). "ZurBildung von $\alpha-\mathrm{FeOOH}$ and $\alpha-\mathrm{Fe}_{2} \mathrm{O}_{3}$ aus amorphem Eisen(III)-hydroxid. III." Z. Anorg. Allg. Chem. 346, 137-142.

Sileo, E. E., Ramos, A. Y., Magaz, G. E., and Blesa, M. A. "Long-range vs. Short-range Ordering in Synthetic Cr-substituted Goethites," in preparation.

Sileo, E. E., Alvarez, M., and Rueda, E. H. (2001). "Structural Studies on the Manganese for Iron Substitution in the Synthetic Goethite-Jacobsite System," Int. Inorg. Mater. 3, 271-279.

Stephens, P. W. (1999). "Phenomenological model of anisotropic bradening in powder diffraction," J. Appl. Crystallogr. 32, 281-289.

Stiers, W. and Schwertmann, U. (1985). "Evidence for Manganese Substitution in Synthetic Goethite." Geochim. Cosmochim. Acta 49, 19091911.

Szytula, A., Burewicz, A., Dimitrijevic, Z., Krasnicki, S., Rzany, H., Todorovic, J., Wanic, A., and Wolski, W. (1980). "Neutron Diffraction Studies of $\alpha$-FeOOH," Phys. Stat. Solidi 26, 429-434.

Thompson, P., Cox, D. E., and Hastings, J. B. (1987). "Rietveld Refinement of Debye-Scherrer Synchrotron X-ray data from $\mathrm{Al}_{2} \mathrm{O}_{3}$,' ' J. Appl. Crystallogr. 20, 79-83.

Vandenberghe, R. E., Verbeeck, A. E., De Grave, E., and Stiers, W. (1986). "Mössbauer Effect Study of Mn-substituted Goethite and Hematite," Hyperfine Interact. 29, 1157-1160.

Venema, P., Hiemstra, T., and Van Riemsdijk, W. H. (1996). "Multisite Adsortion of Cadmium on Goethite," J. Colloid Interface Sci. 183, 515527.

Wolska, E. and Schwertmann, U. (1989). "Nonstoichiometric structures during dehydroxylation of goethite,” Z. Kristallogr. 189, 223-237. 